\title{
The association between injury severity and psychological morbidity, hand function, and return to work in traumatic hand injury with major nerve involvement: A one-year follow-up study
}

\author{
다 Nihal Tezel, M.D., 다 Aslı Can, M.D.
}

Department of Physical Medicine and Rehabilitation, University of Health Sciences Dışkapı Yıldırım Beyazıt

Training and Research Hospital Ankara-Turkey

\begin{abstract}
BACKGROUND: We aimed to investigate the association between the severity of the injury and psychological morbidities, hand functions, and return to work (RTW) in traumatic hand injury (THI) with major nerve involvement.

METHODS: Thirty-two patients had THI with major nerve involvement were enrolled in this study. The demographic and clinical characteristics of the patients were recorded after the injury. The severity of the injury was evaluated using the modified Hand Injury Severity Score (MHISS). The Disabilities of the Arm, Shoulder, and Hand (Q-DASH) score and Duruöz Hand Index (DHI) were used to assess the hand function. Beck Anxiety Inventory (BAI), Beck Depression Inventory (BDI), and Impact of Event Scale-Revised (IES) were performed to assess psychological morbidity. These assessments were performed after injury and at the end of the first year. Time to RTW was recorded in the first year after the injury. Jamar Hand Dynamometer and pinch meter were used for the measurement of hand and finger grip strength at the end of the first year.
\end{abstract}

RESULTS: There were significant improvements in IES-R, BDI, BAI, Q-DASH, and DHI scores at the end of the first year compared with baseline scores. We found a significant correlation between MHISS and time of RTW, Q-DASH, and pinch strengths. We found no significant correlation between MHISS and IES-R, BDI, BAI, and grip strength.

CONCLUSION: The severity of the injury is significantly associated with hand functions, pinch strengths, and RTW in THIs with major nerve involvement. The findings showed that there was no association between the severity of the injury and psychological morbidities in the present study.

Keywords: Hand injury; injury severity score; psychological morbidity.

\section{INTRODUCTION}

Traumatic hand injuries (THIs) are common injuries that affect approximately 10-30\% of the global population. These injuries may lead to limited participation in daily living activities, delayed return to work (RTW), non-return to work, and consequently, severe financial and labor losses. This may also cause additional trauma, including psychological problems, such as depressive symptoms, anxiety, and posttraumatic stress disorder. ${ }^{[1]}$
The severity, type, and characteristics of the injured structures can affect the long-term outcomes and RTW. ${ }^{[2]}$ Tendons, bones, vessels, or nerves in the hand may be damaged by traumatic injuries. ${ }^{[3]}$ Major nerve injuries (median and/or ulnar nerves) are generally related to poor outcomes. ${ }^{[4]}$ The loss of motor and sensory functions after a major nerve injury may profoundly impact functioning and daily living activities. ${ }^{[5]}$

Cite this article as: Tezel N, Can A. The association between injury severity and psychological morbidity, hand function, and return to work in traumatic hand injury with major nerve involvement: A one-year follow-up study. Ulus Travma Acil Cerrahi Derg 2020;26:905-910.

Address for correspondence: Nihal Tezel, M.D.

SBÜ Dışkapı Yıldırım Beyazıt Eğitim ve Araştırma Hastanesi, Fiziksel Tıp ve Rehabilitasyon Kliniği, Ankara, Turkey

Tel: +90 312 - 5962993 E-mail: nihaltezel@gmail.com 
Previous studies have focused on the relationship between the severity of upper extremity traumas, functional disability, and RTW. ${ }^{[2,6,7]}$ On the other hand, the psychological status of the patients may also be affected by the severity of THls. To our knowledge, in the literature, there is no study investigating the relationship between the severity of the injury and psychological morbidity in THI with major nerve involvement. The present study uniquely investigated the association between the severity of the injury and psychological morbidities, hand functions, and RTW in THI with major nerve involvement. We also aimed to investigate the long-term effects of severity of THI on psychological status, hand functions, and RTW.

\section{MATERIALS AND METHODS}

Fifty patients who had THI with major nerve involvement were assessed for eligibility in the study between September 2016 and September 2019. Thirty-two patients were enrolled in this study based on the following inclusion and exclusion criteria. Inclusion criteria were as follows: (i) being over 18 years old; (ii) unilateral traumatic hand injury with median nerve and/or ulnar nerve involvement; (iii) intact hand functions before injury. Exclusion criteria were as follows: (i) previous severe upper extremity injuries; (ii) bilateral hand injuries; (iii) amputations; (iv) additional rheumatologic disorders; (v) inability to understand or follow instructions.

The study protocol was approved by the local Ethics Committee (approval date:18/06/19; approval number: 65/07). A written informed consent was obtained from each patient. This study was conducted in accordance with the principles of the Declaration of Helsinki.

\section{Intervention}

The hand rehabilitation program was started after a 3-week immobilization period for all patients. The rehabilitation program was tailored to the patient's individual needs and applied three days a week for 12 weeks in our outpatient clinic. All patients' demographic characteristics, including age, gender, occupation, injured anatomical structures, and injured side (dominant/non-dominant), were recorded. Return to work after the injury, time of RTW, and return to previous work were recorded at 12 months after the injury. All evaluations were performed face to face with the patients.

\section{Primary Outcome Measures}

The Modified Hand Injury Severity Score (MHISS) was used to assess the severity of forearm, wrist, and hand injuries based on information in patients' folders. It evaluates the integument, bones, tendons, muscles, and neurovascular structures. A higher score indicates a more severe injury.

Psychological morbidities were assessed using the Beck Depression Inventory (BDI), Beck Anxiety Inventory (BAI), and the Impact of Event Scale-Revised (IES-R). Depressive symptoms and anxiety of the patients were assessed by BDI and $\mathrm{BAI}$, respectively. Both inventories are 21 -item self-administered questionnaires. Each item is scored between 0 and 3 points. Higher scores indicate a greater level of anxiety and depression. The Turkish validity and reliability of BDI have been performed by Hisli. ${ }^{[8]}$ The Turkish validity and reliability of BAI has been performed by Ulusoy et al. ${ }^{[9]}$

The IES- $R$ is a 22-item self-report questionnaire that evaluates the degree of distress after traumatic events. Each item is scored on a 5-point scale ranging from 0 (not at all) to 4 (extremely). The validity and reliability study of the Turkish version of IES-R was performed by Çorapçıoğlu et al. ${ }^{[10]}$

Hand functions were evaluated using the Quick Disabilities of the Arm, Shoulder and Hand score (Q-DASH) and Duruöz Hand Index (DHI). Q-DASH is a self-report questionnaire that contains II items. Each item is scored from I to 5 points. High scores indicate a lower functional level. The validity and reliability of the Turkish version of Q-DASH was performed by Düger et al. ${ }^{\left[{ }^{\prime \prime}\right]}$

Duruöz Hand Index (DHI) is a self-report questionnaire that contains 18 items related to hand functions. Each item is scored from 0 (no difficulty) to 5 (impossible to do). The total score ranges from 0 to 90 with higher scores, indicating poorer hand functioning. It is a reliable and valid questionnaire to evaluate hand functions in patients with traumatic hand injuries. ${ }^{[12]}$

All patients were assessed early after the injury (within three weeks) using the MHISS. The BDI, BAI, IES-R, Q-DASH, and $\mathrm{DHI}$ were performed within three weeks after a traumatic injury and at the end of the first year.

\section{Secondary Outcome Measures}

Grip strength is one of the indicators of the functional use of the hand. It was measured using a Jamar hydraulic hand dynamometer. Lateral pinch, 2-point pinch, and 3-point pinch strengths were measured using a Jamar hydraulic pinch gauge (Bolingbrook, IL, USA). Patients were seated with shoulder adducted, elbow $90^{\circ}$ flexed, and forearm and wrist in a neutral position. Patients were encouraged to press as firmly as possible. Three consecutive measurements were performed. The average of the measurements was recorded in kilograms $(\mathrm{kg})$. We evaluated the strengths of both healthy hand and injured hand in all patients at the end of the 12 months.

\section{Statistics}

The Kolmogorov-Smirnov test was used to evaluate the distribution of normality. We performed paired t-test for normally distributed data and Wilcoxon signed rank test for non-normally distributed data to compare the clinical characteristics. 
Descriptive data were expressed in \%, mean \pm SD or median (min-max). Spearman's rank correlation coefficients were used to evaluate the relation between the MHISS and time of RTW, baseline Q-DASH, baseline DHI, baseline BDI, baseline BAI, baseline IES-R, grip strength, and pinch strengths. Spearman's rank correlation coefficients were accepted as follows: $0.8 \mathrm{I}-\mathrm{I} .0$ as excellent, $0.6 \mathrm{I}-0.80$ very good, $0.4 \mathrm{I}-0.60 \mathrm{good}$, $0.21-0.40$ fair, and 0-0.20 poor. $^{[13]}$ SPSS version 17 (SPSS Inc., Chicago, IL, USA) was used for all statistical analyses. p-values less than .05 were accepted as statistically significant.

\section{RESULTS}

In this study, 32 patients were included. Of these patients, 29 were male $(90.6 \%)$ and three were female $(9.4 \%)$. Their mean

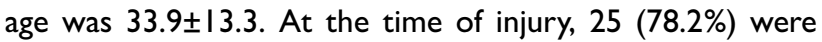
workers. Eight of the 25 patients (32\%) returned to work after the injury. While seven of these patients (87.5\%) returned to previous work, one patient (I2.5\%) changed the work the after injury. The mean time of RTW was $69.6 \pm 32.8$ days. The mean score of the MHISS was $84.5 \pm 34.2$. The demographic and baseline clinical characteristics of the patients have been shown in Table I.

Table I. Demographic and baseline clinical characteristics of the patients

\begin{tabular}{|c|c|}
\hline Age $($ mean $\pm S D)$ & $33.9 \pm 13.3$ \\
\hline \multicolumn{2}{|l|}{ Gender, n (\%) } \\
\hline Male & $29(90.6)$ \\
\hline Female & $3(9.4)$ \\
\hline \multicolumn{2}{|l|}{ Occupation, n (\%) } \\
\hline Worker & $25(78.2)$ \\
\hline Student & $3(9.4)$ \\
\hline Retired & $2(6.2)$ \\
\hline Unemployment & $2(6.2)$ \\
\hline \multicolumn{2}{|l|}{ Injured structures, n (\%) } \\
\hline Nerve & $4(12.5)$ \\
\hline Nerve+tendon & $19(59.3)$ \\
\hline Nerve+tendon+vessel & $9(28.1)$ \\
\hline \multicolumn{2}{|l|}{ Injured hand, n (\%) } \\
\hline Dominant & $18(56.3)$ \\
\hline Non-dominant & 14 (43.7) \\
\hline \multicolumn{2}{|l|}{ Return to work after injury, n (\%) } \\
\hline Yes & $8(32)$ \\
\hline No & $17(68)$ \\
\hline Return to previous work, $\mathrm{n}(\%)$ & $7(87.5)$ \\
\hline $\begin{array}{l}\text { Time of return to work (day) } \\
(\text { mean } \pm S D)(\text { min-max) }\end{array}$ & $69.6 \pm 32.8(15-100)$ \\
\hline MHISS (mean $\pm S D)$ (min-max) & $84.5 \pm 34.2(20-|5|)$ \\
\hline
\end{tabular}

MHISS: Modified Hand Injury Severity Score; SD: Standard deviation.
At the end of the 12 months, there were significant improvements in the BAI, BDI, IES-R, Q-DASH, and DHI scores compared with baseline scores. Clinical parameters of the patients at baseline and 12-month follow-up are shown in Table 2.

At the end of the 12 months, the mean grip strength of the injured hand was $46.8 \%$ of the intact hand, the mean of 2-point pinch strength was $38.1 \%$ of the intact hand, the mean of 3 -point pinch strength was $41.2 \%$ of the intact hand, and the lateral pinch strength was $36.1 \%$ of the intact hand. The mean values of the hand strengths at the end of the 12 months are shown in Table 3.

The Spearman's correlation analysis revealed that there were significant good correlations between the MHISS and $Q-D A S H$, lateral pinch strength and 2-point pinch strength $(r=0.60, p=0.02 ; r=0.82, p=0.01 ; r=0.43, p=0.02$; respectively). The MHISS was weakly, but significantly correlated with time of RTW and 3-point pinch strength $(r=0.30, p=0.04$ and $r=0.39, p=0.03$, respectively). However, we found no significant correlations between the MIHSS and IES-R, BAI, BDI, grip strength, and $\mathrm{DHI}(r=0.0 \mathrm{I}, \mathrm{p}=0.93 ; r=-0.07, p=0.7 \mathrm{I} ; \mathrm{r}=-$ $0.04, p=0.79 ; r=0.25, p=0.02 ; r=0.16, p=0.37$, respectively). Correlation of the MHISS with clinical characteristics of the patients is shown in Table 4.

Table 2. Clinical parameters of the patients at baseline and I2-month follow-up [(mean $\pm S D)$ or median (min$\max )$ ]

\begin{tabular}{lcccc}
\hline & Baseline & $\begin{array}{c}\text { I2-month } \\
\text { follow-up }\end{array}$ & Z,t & p \\
\hline IES-R & $40(0-80)$ & $12(0-59)$ & $-4.9(\mathrm{Z})$ & $<0.00 I^{*}$ \\
BDI & $I I .5(0-55)$ & $3(0-34)$ & $-3.9(\mathrm{Z})$ & $<0.00 I^{*}$ \\
BAI & $10(0-55)$ & $2.5(0-50)$ & $-4.4(\mathrm{Z})$ & $<0.00 I^{*}$ \\
Q-DASH & $59.4 \pm 18.8$ & $34.8 \pm I 8.1$ & $5.8(\mathrm{t})$ & $0.002^{*}$ \\
DHI & $48.1 \pm 23.9$ & $30.2 \pm 20.4$ & $1 \mathrm{I} .5(\mathrm{t})$ & $<0.00 I^{*}$ \\
\hline
\end{tabular}

BAI: Beck Anxiety Inventory; BDI: Beck Depression Inventory; Q-DASH: Quick Disabilities of the Arm, Shoulder and Hand; DHI: Duruöz Hand Index; IES-R: Impact of Event Scale-Revised; SD: Standard deviation. *: Statistically significant difference.

Table 3. The mean hand strengths values at the end of the 12 months (mean \pm SD)

\begin{tabular}{lcc}
\hline & Intact hand & Injured hand \\
\hline Grip strength $(\mathrm{kg})$ & $35.8 \pm 5.7$ & $16.3 \pm 9.6$ \\
Lateral pinch strength $(\mathrm{kg})$ & $10.3 \pm 4.3$ & $3.5 \pm 1.2$ \\
2-point pinch strength $(\mathrm{kg})$ & $10.1 \pm 2.9$ & $3.6 \pm 1.5$ \\
3-point pinch strength $(\mathrm{kg})$ & $10 \pm 2.6$ & $3.9 \pm 1.5$ \\
\hline
\end{tabular}

SD: Standard deviation. 
Table 4. Correlation of the MHISS scores with clinical characteristics of the patients

MHISS (r)

\begin{tabular}{lc} 
Time of return to work & $0.30^{*}$ \\
IES-R & 0.01 \\
BAI & -0.07 \\
BDI & -0.04 \\
Q-DASH & $0.60^{*}$ \\
DHI & 0.16 \\
Grip strength & 0.25 \\
Lateral pinch strength & $0.82^{*}$ \\
2-point pinch strength & $0.43^{*}$ \\
3-point pinch strength & $0.39^{*}$ \\
\hline
\end{tabular}

BAI: Beck Anxiety Inventory; BDI: Beck Depression Inventory; DHI: Duruöz Hand Index; IES-R: Impact of Event Scale-Revised; MHISS: Modified Hand Injury Severity Score; Q-DASH: Quick Disabilities of the Arm, Shoulder and Hand, $r$ : Spearman's correlation coefficient. *: Statistically significant difference.

\section{DISCUSSION}

Traumatic injuries may lead to trauma-related psychiatric disorders. Post-traumatic distress disorder, depression, and anxiety are the most common psychological morbidities following traumatic injuries. ${ }^{[14,15]}$ Both severity and site of traumatic injuries may be related to psychological disorders after the traumatic injury. ${ }^{[16]}$ To our knowledge, there is no study to evaluate the association between the severity of the injury and psychological morbidity in THls with major nerve involvement. In this study, we evaluated the association between the severity of the injury and psychological morbidities, functioning, and RTW in THls with major nerve involvement.

The MHISS was designed to grade the severity of THls and to predict the injury outcomes. The MHISS results can be categorized into four groups: a score of $\leq 20$ indicates a mild THI; a score of $2 \mathrm{I}-50$ indicates a moderate $\mathrm{THI}$, a score of $5 \mathrm{I}-100$ reflects a severe $\mathrm{THI}$; and a score of $\geq 10 \mathrm{I}$ correlates with

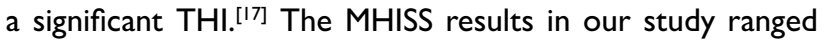
from 20-15I, with a mean value of 84.5. This result suggests that most of our patients had severe injury.

The psychological effects of hand injuries are the most common in the first month following injury and begin to reduce significantly within 6-9 months. The effects may maintain even after 18 months. ${ }^{[18]}$ O'Donnell et al. reported that prevalence rates of post-traumatic distress disorder, depression, and anxiety decreased at 12 months after the injury. ${ }^{[15]} \mathrm{Sim}$ ilarly, we detected significant improvements in symptoms of anxiety, depression, and post-traumatic distress disorder in THI patients at the end of the 12 months compared with symptoms in the first three weeks. We also detected that hand functions (Q-DASH and DHI scores) improved significantly at the end of the 12 months compared with baseline hand functions. Similar to our results, Dogu et al. ${ }^{[8]}$ found a significant improvement in hand functions at 6-9 months after the hand injury. On the other hand, we detected that grip and pinch strengths of the injured hand remained under the uninjured hand strengths in 12 months after the injury. We did not assess injured hand strengths early after the injury because of 3-week immobilization splint usage. On the other hand, we assumed that hand strength tend to increase because a close association has been known between hand function and hand strength.

Psychological disorders have a negative effect on general health status after THI. The most frequent types of psychopathology associated with hand trauma are posttraumatic distress disorder and depression. Approximately one-third of patients with THI has symptoms of these psychological disorders. ${ }^{[19]}$ There are some studies to evaluate the psychological impacts of the hand injury. ${ }^{[18-20]}$ Our study differed from previous studies in that we investigated the association between the severity of the injury and psychological morbidities in $\mathrm{THI}$ with major nerve involvement. In the present study, we found no correlation between the injury severity and symptoms of posttraumatic distress disorder, depression, and anxiety. This result can be attributed to the small sample size of the study and assessment tools have been used.

Major nerve injuries of hand seem to delay RTW more than other injuries, such as tendon injuries and digital nerve injuries. ${ }^{[20,21]}$ In the present study, only $32 \%$ of the patients returned to work within 12 months after injury. The mean time to RTW was detected to be 70 days. Similar to our results, Marom et al. ${ }^{[1]}$ reported that the mean time to RTW was 94 days. Contrastly, Bruyns et al. ${ }^{[22]}$ found that $59 \%$ of patients with nerve injury returned to work after injury and the meantime was approximately 220 days. Different results can be explained by different kinds of jobs and different characteristics of injury, such as additional injured structures and the severity of injuries. In our study, most of the patients had additional tendon and/or vessel injuries and most of them had a severe injury.

The severity of the injury is the most important factor to RTW after hand injuries. ${ }^{[7]}$ In the present study, we found that the severity of THI was positively correlated with the time of RTW. Consistent with our result, Lee et al. ${ }^{[7]}$ reported that there was a significant relationship between the severity of the injury and the probability of RTW. Çakır et al. ${ }^{[2]}$ also found a significant relationship between the severity of the injury and the time of RTW in patients with hand and forearm injuries. According to these results, patients with severe injuries were significantly less likely to RTW than patients with less severe injuries.

The injury severity in the initial evaluation of patients is an important factor for determining the disability level. Çapkın et al. ${ }^{[6]}$ reported a statistically significant correlation between 
the MHISS and hand disability. Similarly, in the present study, the severity of THI was positively correlated with hand functions. We also detect a correlation between the severity of hand injury and pinch strengths, but no correlation was found with grip strength. In contrast to our results, Çakır et al. ${ }^{[2]}$ found a significant correlation between the severity of hand injury and grip strength. They did not assess the pinch strengths of the patients.

This study has several limitations. First, the small sample size is small and no power analysis was performed to calculate the study sample size. Larger sample size would have been more powerful. Second, we included not only patients with major nerve injury but also patients with tendon and/or vessel injuries.

\section{Conclusion}

Severity of injury is significantly associated with hand functions, pinch strengths, and RTW in THls with major nerve involvement. There was no association between severity of the injury and psychological morbidities in the present study. Future studies with a larger sample size are needed to confirm the relationship between the severity of the injury and psychological morbidities in THI with nerve involvement.

Ethics Committee Approval: Turkish Ministry of Health, Health Sciences University, Dışkapı Yıldırım Beyazıt Training and Research Hospital, Clinical Research Ethics Committee granted approval for this study (date: 18.06.2019, number: 65/07).

Peer-review: Internally peer-reviewed.

Authorship Contributions: Concept: A.C.; Design: A.C.; Supervision: N.T., A.C.; Resource: N.T., A.C.; Data: N.T., A.C.; Analysis: A.C.; Literature search: N.T., A.C.; Writing: N.T., A.C.; Critical revision: N.T., A.C.

Conflict of Interest: None declared.

Financial Disclosure: The authors declared that this study has received no financial support.

\section{REFERENCES}

1. Marom BS, Ratzon NZ, Carel RS, Sharabi M. Return-to-Work Barriers Among Manual Workers After Hand Injuries: 1-Year Follow-up Cohort Study. Arch Phys Med Rehabil 2019;100:422-32. [CrossRef]

2. Çakır N, Özcan RH, Kitiş A, Büker N. Investigation of Relationship Between Severity of Injury, Return to Work, Impairment and Activity Participation in Hand and Forearm Injuries. Ulus Travma Acil Cerr Derg 2014;20:120-6. [CrossRef]

3. Ozçelik B, Ertürer E, Mersa B, Purisa H, Sezer I, Tunçer S, et al. An alternative classification of occupational hand injuries based on etiologic mechanisms: the ECOHI classification. Ulus Travma Acil Cerrahi Derg 2012;18:49-54. [CrossRef]

4. Bucknam RB, Dunn JC, Fernandez I, Nesti LJ, Gonzalez GA. Outcomes and return to work following complex nevre lacerations in the volar forearm in an underserved Spanish-speaking population. JHSGO 2020;2:67-73. [CrossRef]

5. Dahlin LB, Wiberg M. Nerve injuries of the upper extremity and hand. EFORT Open Rev 2017;2:158-70. [CrossRef]

6. Çapkın S, Cavit A, Yllmaz K, Erdoğan E, Kaleli T. Associations between initial injury severity in acute hand, wrist or forearm injuries and disability ratings and time to return to work. Ulus Travma Acil Cerrahi Derg 2020;26:453-61. [CrossRef]

7. Lee YY, Chang JH, Shieh SJ, Lee YC, Kuo LC, Lee YL. Association between the initial anatomical severity and opportunity of return to work in occupational hand injured patients. J Trauma 2010; 69(6):e88-93.

8. Hisli N. Beck Depresyon Envanterinin üniversite ögrencileri için geçerliligi ve güvenilirligi. J Psychol 1989;7:3-13.

9. Ulusoy M, Şahin NH, Erkmen H. Turkish Version of the Beck Anxiety Inventory. J Cognitive Psychotherapy 1998;12:163-72.

10. Çorapçıŏlu A, Yargıç İ, Geyran P, Kocabaşoğlu N. Olayların Etkisi Ölçeği (IES-R) Türkçe Versiyonunun Geçerlilik ve Güvenilirliği. New Symp J 2006;44:14-22.

11. Düger T, Yakut E, Öksüz Ç, Yörükan S, Bilgütay B, Ayhan Ç. Kol, omuz ve el sorunlar1 (disabilities of the arm, shoulder and hand-DASH) anketi Türkçe uyarlamasının güvenirliği ve geçerliği. Fizyoter Rehabil 2006;17:99-107.

12. Erçalik T, Şahin F, Erçalik C, Doğu B, Dalgiç S, Kuran B. Psychometric characteristics of Duruoz Hand Index in patients with traumatic hand flexor tendon injuries. Disabil Rehabil 2011;33:1521-7. [CrossRef]

13. Feise RJ, Michael Menke J. Functional rating index: a new valid and reliable instrument to measure the magnitude of clinical change in spinal conditions. Spine (Phila Pa 1976) 2001;26:78-87. [CrossRef]

14. O'Donnell ML, Creamer MC, Parslow R, Elliott P, Holmes AC, Ellen $\mathrm{S}$, et al. A predictive screening index for posttraumatic stress disorder and depression following traumatic injury. J Consult Clin Psychol 2008;76:923-32. [CrossRef]

15. O'Donnell ML, Creamer M, Bryant RA, Schnyder U, Shalev A. Posttraumatic disorders following injury: an empirical and methodological review. Clin Psychol Rev 2003;23:587-603. [CrossRef]

16. Baecher K, Kangas M, Taylor A, O'Donnell ML, Bryant RA, Silove D, et al. The role of site and severity of injury as predictors of mental health outcomes following traumatic injury. Stress Health 2018;34:545-51.

17. Campbell DA, Kay SP. The Hand Injury Severity Scoring System. J Hand Surg Br 1996;21:295-8. [CrossRef]

18. Dogu B, Kuran B, Sirzai H, Sag S, Akkaya N, Sahin F. The relationship between hand function, depression, and the psychological impact of trauma in patients with traumatic hand injury. Int J Rehabil Res 2014;37:105-9. [CrossRef]

19. Williams AE, Newman JT, Ozer K, Juarros A, Morgan SJ, Smith WR. Posttraumatic stress disorder and depression negatively impact general health status after hand injury. J Hand Surg Am 2009;34:515-22.

20. Opsteegh L, Reinders-Messelink HA, Schollier D, Groothoff JW, Postema K, Dijkstra PU, et al. Determinants of return to work in patients with hand disorders and hand injuries. J Occup Rehabil 2009;19:245-55.

21. Meiners PM, Coert JH, Robinson PH, Meek MF. Impairment and employment issues after nerve repair in the hand and forearm. Disabil Rehabil 2005;27:617-23. [CrossRef]

22. Bruyns CN, Jaquet JB, Schreuders TA, Kalmijn S, Kuypers PD, Hovius SE. Predictors for return to work in patients with median and ulnar nerve injuries. J Hand Surg Am 2003;28:28-34. [CrossRef] 


\section{ORİIINAL ÇALIŞMA - ÖZET}

\section{Majör sinir tutulumu olan travmatik el yaralanmalarında yaralanma şiddeti ile psikolojik morbidite, el fonksiyonu ve işe dönüş arasındaki ilişki: Bir yıllık takip çalışması}

\section{Dr. Nihal Tezel, Dr. Aslı Can}

Sağlık Bilimleri Üniversitesi Dışkapı Yıldııı Beyazıt Eğitim ve Araştırma Hastanesi, Fiziksel Tıp ve Rehabilitasyon Kliniği, Ankara

AMAÇ: Travmatik el yaralanmalarında, majör sinir etkilenimi ile yaralanma şiddeti ile psikolojik morbidite, el fonksiyonları ve işe dönüş zamanı arasındaki ilişkiyi araştırmayı amaçladık.

GEREÇ VE YÖNTEM: Çalışmaya majör sinir tutulumu olan 32 hasta alındı. Yaralanma sonrası hastaların demografik ve klinik özellikleri kaydedildi. Yaralanmanın şiddeti, El Yaralanması Ciddiyet Skoru (EYCS) kullanılarak değerlendirildi. El fonksiyonunu değerlendirmek için Kol, Omuz ve El (Q-DASH) skorları ve Duruöz El İndeksi (DEi) kullanıldı. Psikolojik morbidite Beck Anksiyete Envanteri (BAE), Beck Depresyon Envanteri (BDE) ve Olay Etkisi Ölçeği-Revize (OEÖ-R) ile değerlendirildi. Bu değerlendirmeler yaralanmadan sonra ve ilk yllın sonunda yapıldı. İşe dönüş zamanı yaralanmadan sonraki ilk yılda kaydedildi. El ve parmak kavrama kuvvetinin ölçümü için Jamar El Dinamometresi ve pinçmetre kullanıldı.

BULGULAR: YIl sonunda OEÖ-R, BDE, BAE, Q-DASH ve DEI skorlarında başlangıç skorlara göre önemli iyileşmeler oldu. EYCS ile işe dönüş zamanı, Q-DASH ve el ve parmak kuvvetleri arasında anlamlı bir korelasyon bulundu. ECYS ile OEÖ-R, BDE, BAE ve kavrama kuvveti arasında anlamlı bir ilişki bulunmadı.

TARTIŞMA: Majör sinir tutulumu olan travmatik el yaralanmalarında yaralanmanın şiddeti el fonksiyonları, kavrama kuvvetleri ve işe dönüş zamanı ile önemli ölçüde ilişkilidir. Bu çalışmada, yaralanmanın şiddeti ile psikolojik morbidite arasında bir ilişki bulunmamıştır.

Anahtar sözcükler: El yaralanması; kavrama kuvveti; yaralanma şiddeti skoru.

Ulus Travma Acil Cerrahi Derg 2020;26(6):905-910 doi: 10.14744/tjtes.2020.39472 